Original Research Article

\title{
An analysis of the pattern and profile of adverse drug reactions reported at a tertiary care teaching hospital in Kerala, India: a retrospective record based observational study
}

\author{
Abdul Aslam P. ${ }^{1}$, Sangeetha Purushothaman ${ }^{2 *}$, Jihana Shajahan ${ }^{2}$
}

\begin{abstract}
${ }^{1}$ Department of Pharmacology, Government Medical College, Manjeri, Kerala, India ${ }^{2}$ Department of Pharmacology, Travancore Medical College, Kollam, Kerala, India
\end{abstract}

Received: 19 June 2018

Accepted: 26 July 2018

*Correspondence to:

Dr. Sangeetha Purushothaman, Email: sangeethap85@ gmail.com

Copyright: () the author(s), publisher and licensee Medip Academy. This is an openaccess article distributed under the terms of the Creative Commons Attribution NonCommercial License, which permits unrestricted noncommercial use, distribution, and reproduction in any medium, provided the original work is properly cited.

\begin{abstract}
Background: Adverse drug reactions (ADRs) are an important concern in modern therapeutics. Due to limitations in identifying ADRs during research phase, organized post marketing studies are essential. However, there are only few recent studies on this subject available in India. Hence this study was done in a tertiary care hospital in South Kerala to evaluate the profile and causality of ADRs.

Methods: The details of patients who developed ADRs during the period from October 2016 to November 2017 were collected. Data collection was done using the suspected drug reactions monitoring form by CDSCO used under PvPI and a retrospective observational cross-sectional analysis was done. The profile and causality of ADRs were evaluated.

Results: The total number of ADR events reported was 300.179 ADRs were hypersensitivity reactions (Aronson Type B) and the remaining 121 reactions were Type A reactions. The individual drug class causing majority of the ADRs was antibiotics (36\%). Commonest significant dose related ADR was bleeding (7\%) caused by combined use of antiplatelets and anticoagulants. The organ system most affected as per SOC classification was skin and appendages (56\%). Causality assessment revealed that majority (76\%) belonged to "probable" category, whereas $23.6 \%$ were of "possible" type.

Conclusions: The development of ADRs can significantly affect treatment course - interruption of drug therapy, use of additional drugs and prolonged hospital stay. Employing monitors dedicated to ADR detection and education of prescribers to closely monitor patients can help manage ADRs effectively.
\end{abstract}

Keywords: Adverse drug reactions, Causality, Pharmacovigilance

\section{INTRODUCTION}

In the era of modern medicine drugs are very commonly used. Usage of drugs not only results in beneficial effects but also may result in some unexpected or noxious effects commonly known as adverse drug reactions (ADRs). No drug is exempt from the potential of ADR. As defined by the WHO, ADR is any noxious, unintended and undesired effect of the drug which occurs at doses used in humans for prophylaxis, diagnosis or therapy of a disease or the modification of the physiological state. ${ }^{1}$ Pharmacovigilance is the branch of pharmacology which deals with detection, assessment, understanding and prevention of ADRs.

It is vital to detect ADRs in a timely manner. During drug development, animal toxicity studies and clinical trials are done to assure the safety of drugs. Still, these cannot guarantee absolute safety when a drug is marketed for large scale use. Continuous monitoring of drug effects and side effects are essential for rational therapy. A wellestablished pharmacovigilance system is essential for the same. Post marketing studies and spontaneous reporting of ADR fill the void in the information we possess, especially 
with respect to the long term effects and the use in the patient population with comorbidities. Uppsala monitoring centre (UMC) in Sweden is the WHO collaborating centre internationally for ADR monitoring. ${ }^{2} \mathrm{UMC}$ developed and maintains a global individual case safety report database known as Vigibase on behalf of WHO. ${ }^{3}$

In India, the Pharmacovigilanceprogramme (PvPI) was initiated in $2010 .{ }^{4}$ ADR monitoring centers (AMC) have been set in different parts of the country under PvPI to enhance and ensure the safety of patients. ${ }^{5}$ Presently there are around 250 AMCs across the country attached to medical colleges and hospitals. AMC of Travancore medical college, Kollam, Kerala is one of the recently approved AMCs under PvPI.

There are studies from the west regarding ADRs in hospitalized patients, however information from India is lacking. Hence, the current study was undertaken to analyze the profile of ADRs in a tertiary care teaching hospital in Kerala, India.

\section{METHODS}

A retrospective observational cross-sectional analysis was carried out for the data collected from November 2016 to October 2017 (one year) to evaluate the prevalence and profile of ADRs. The study was done in a tertiary care teaching hospital from south India which is an ADR Monitoring Centre (AMC), working under Pharmacovigilance Programme of India (PvPI).

Institute Ethics Committee (IEC) permission was taken prior to commencement of the study.

Any ADR reported to the ADR Monitoring Centre by the healthcare professionals and students of the institution, reported in CDSCO suspected ADR.

Information about patient, like age, sex, details of the reaction, details of suspected drugs, concomittant medications, details of treatment for ADR if any and laboratory investigations were noted. Facts needed to assess causality and seriousness of reaction were collected. The information about de-challenge, re-challenge and the outcome of reaction were recorded as recommended under PvPI.

The suspected ADRs were classified using Aronson classification and SOC classification. ${ }^{6,7}$

In Aronson classification, adverse drug reactions are classified into 5 subtypes - A to F. Type A ADRs are dosedependent and predictable; they are augmentations of known pharmacologic effects of the drug, such as hypoglycaemia with insulin or sedation with morphine. They are also known as augmented reactions.

Type B ADRs are uncommon and unpredictable, not related to the known pharmacology of the drug; they are independent of dose and affect a small population, suggesting that individual patient host factors are important. Hypersensitivity (allergic) reactions to drugs are examples of type B ADRs. They are also known as bizarre reactions. Other types are chronic reactions, which relates to dose and time (type C), Delayed reactions (type D), End of treatment or Withdrawal reactions (Type E), and Failure of therapy (Type F).

In SOC classification, ADRs are classified according to the organ system affected. For e.g.; ADRs affecting the respiratory tract, $\mathrm{CNS}$ etc.

Causality assessment evaluates the relationship between a drug and the occurrence of an adverse event. It has become an integral part of pharmacovigilance. The common tools used for Causality assessment are WHO -UMC scale and the Naranjo's scale. The WHO scale was used in this study. According to this scale, ADRs fall into the following categories- certain, probable, possible, unlikely, unclassified and unclassifiable.

WHO-UMC causality categories are mentioned as WHOUMC scale in Annexure I.

Analysis of data was done using computer software SPSS Version 16 for windows (SPSS, Inc., Chicago, USA). Chisquare test was applied for statistical comparison.

\section{RESULTS}

The total number of ADR events reported during the one year study period was 300. 179 ADRs were hypersensitivity reactions (Aronson Type B). The rest 121 reactions were Type A reactions (Table 1). The individual drug class responsible for most of the ADRs was antibiotics (36\%); the group which caused maximum no of ADR was beta lactam antibiotics (Cephalosporins and Penicillins).

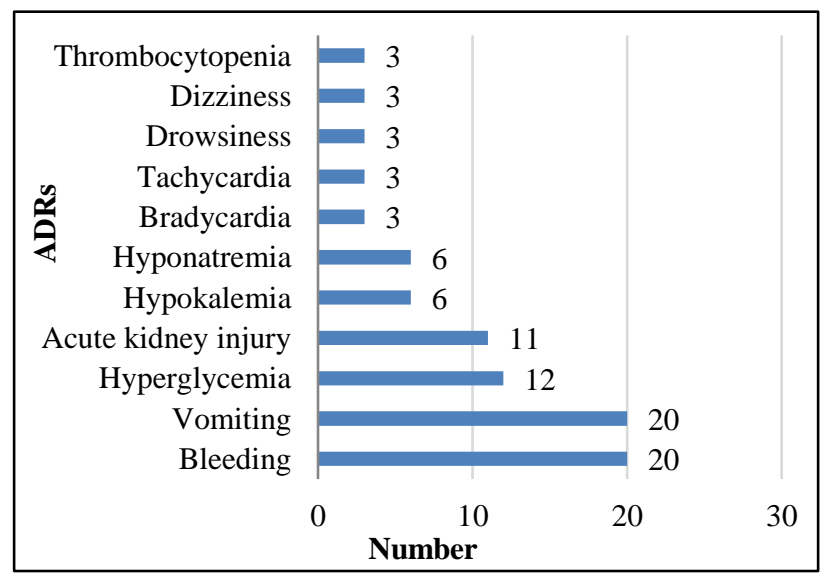

Figure 1: Common type A reactions.

Among the 121 type $\mathrm{A}$ reactions, commonest were bleeding and vomiting (6.6\% each), Hyperglycemia (4\%), Acute kidney injury $(3.6 \%)$, Hypokalemia and 
Hyponatremia (2\% each). The rest of the type A reactions are shown in Figure 1. Incidence of hepatic dysfunction was unexpectedly low (1\%). The list of other common ADRs are depicted in Table 2.

Other drug classes were NSAIDS (11\%), Thrombolytics (7\%), steroids, Nootropicsand Opioids (5\% each) and Antiepileptics (4\%). Other classes are depicted in Figure 2.

Table 1: Profile of adverse drug reactions.

\begin{tabular}{|c|c|c|}
\hline \multicolumn{2}{|c|}{ Study parameters } & Variables \\
\hline \multicolumn{2}{|c|}{ Total number of ADRs } & 300 \\
\hline \multicolumn{2}{|l|}{ Mean age } & $47.8 \% \pm 20$ \\
\hline \multirow{2}{*}{$\begin{array}{l}\text { Sex distribution } \\
(\%)\end{array}$} & Male & 42 \\
\hline & Female & 58 \\
\hline \multirow{3}{*}{$\begin{array}{l}\text { Age-wise } \\
\text { classification } \\
(\%)\end{array}$} & Adult & 69 \\
\hline & Geriatric & 27 \\
\hline & Paediatric & 4 \\
\hline \multirow{6}{*}{$\begin{array}{l}\text { Route of drug } \\
\text { administration } \\
(\%)\end{array}$} & Oral & 35 \\
\hline & IV & 36 \\
\hline & $\mathrm{IM}$ & 2 \\
\hline & $\mathrm{SC}$ & 3 \\
\hline & ID & 15 \\
\hline & Inhalation & 2 \\
\hline \multirow{2}{*}{ Nature $(\%)$} & Serious & 39 \\
\hline & non serious & 61 \\
\hline \multirow{6}{*}{$\begin{array}{l}\text { Type of } \\
\text { reactions (\%) }\end{array}$} & A & 40 \\
\hline & $\mathrm{B}$ & 60 \\
\hline & $\mathrm{C}$ & 0 \\
\hline & $\mathrm{D}$ & 0 \\
\hline & $\mathrm{E}$ & 0 \\
\hline & Unclassified & 0 \\
\hline \multirow{6}{*}{$\begin{array}{l}\text { Causality as per } \\
\text { WHO - UMC } \\
\text { scale }(\%)\end{array}$} & Certain & 0 \\
\hline & Probable & 76 \\
\hline & Possible & 24 \\
\hline & Unlikely & 0 \\
\hline & Unclassified & 0 \\
\hline & Unclassifiable & 0 \\
\hline \multirow{5}{*}{ Outcome (\%) } & Recovered & 64 \\
\hline & Recovering & 30 \\
\hline & Continuing & 3 \\
\hline & Unknown & 2 \\
\hline & Death & 0.3 \\
\hline \multirow[b]{2}{*}{$\begin{array}{l}\text { Management } \\
(\%)\end{array}$} & Intervention required & 52 \\
\hline & $\begin{array}{l}\text { No intervention } \\
\text { required }\end{array}$ & 48 \\
\hline \multirow{4}{*}{$\begin{array}{l}\text { Dechallenge } \\
\text { status }(\%)\end{array}$} & Drug stopped & 91 \\
\hline & Dose reduced & 3 \\
\hline & Drug continued & 2 \\
\hline & unknown & 4 \\
\hline
\end{tabular}

The organ system most affected as per SOC classification was skin and appendages $(56 \%)$. This was followed by gastrointestinal system and Metabolism (8\% each).

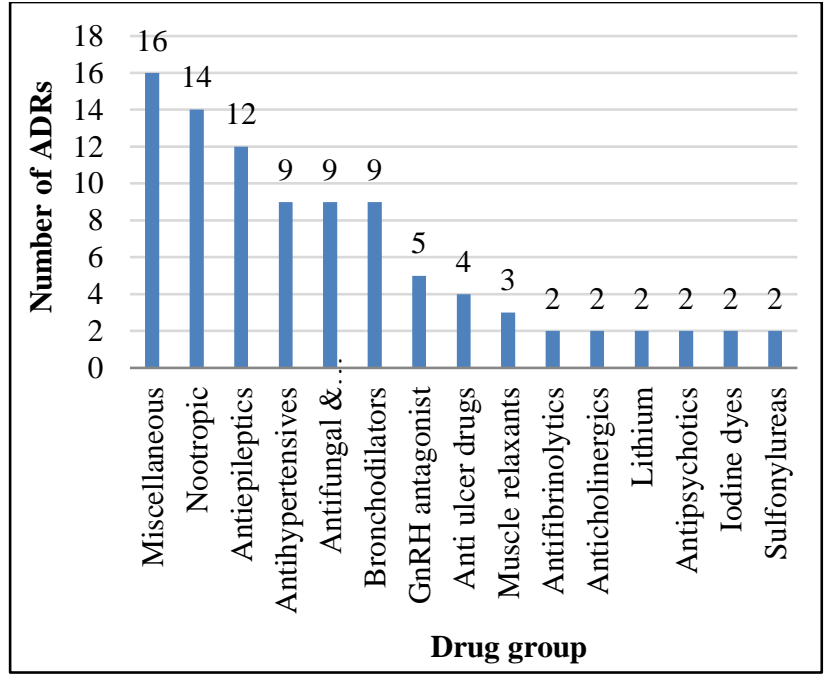

Miscellaneous: anti-cholinergic, antitussive, anti-serum, plasma expanders, general anaesthetics

Figure 2: Details of causal drug groups causing adverse drug reactions $(n=300)$.

Table 2: Details of affected body system and clinical presentation of the adverse drug.

\begin{tabular}{|c|c|}
\hline $\begin{array}{l}\text { Body system } \\
\text { affected (as } \\
\text { per SOC) }\end{array}$ & $\begin{array}{l}\text { Clinical presentation of the affected } \\
\text { system (Number of ADRs) }\end{array}$ \\
\hline $\begin{array}{l}\text { Central and } \\
\text { peripheral } \\
\text { nervous system }\end{array}$ & $\begin{array}{l}\text { Giddiness (6), Altered sensorium (1), } \\
\text { Drowsiness (3), Mania (1), Tremor (2), } \\
\text { Acute muscular dystonia (3), } \\
\text { Intracerebral bleed (1), Epistaxis (1) }\end{array}$ \\
\hline Cardiovascular & Bradycardia (3), Tachycardia (4) \\
\hline Respiratory & Dyspnoea (8), Cough (3), Hemoptysis (4) \\
\hline Urinary system & $\begin{array}{l}\text { Deranged RFT (11), Hematuria(10), } \\
\text { Pedal edema (1), Hyperammonemia (1) }\end{array}$ \\
\hline Gastrointestinal & $\begin{array}{l}\text { Vomiting (21), Dyspepsia (2), Diarrhoea } \\
\text { (2), Constipation (1), Hematemesis (2) }\end{array}$ \\
\hline $\begin{array}{l}\text { Liver and } \\
\text { biliary system }\end{array}$ & Deranged LFT (2), Jaundice (1) \\
\hline $\begin{array}{l}\text { Vascular, Red } \\
\text { blood cell, } \\
\text { White cells and } \\
\text { reticulo- } \\
\text { endothelial } \\
\text { system }\end{array}$ & $\begin{array}{l}\text { Thrombocytopenia (3), Pancytopenia (1), } \\
\text { Anaemia (2), Haemoconcentration (1), } \\
\text { Thrombophlebitis (1) }\end{array}$ \\
\hline $\begin{array}{l}\text { Metabolic and } \\
\text { nutritional: }\end{array}$ & $\begin{array}{l}\text { Hyperglycemia(12), Cushing's syndrome } \\
\text { (1), Hyponatremia (5), Hypokalemia (6), } \\
\text { Hyperkalemia (1), Hypoglycemia (2) }\end{array}$ \\
\hline $\begin{array}{l}\text { Body as a } \\
\text { whole general }\end{array}$ & $\begin{array}{l}\text { Anaphylaxis (3), Shivering (6), Ovarian } \\
\text { hyper stimulation syndrome (OHSS) (1), } \\
\text { Raised INR (1) }\end{array}$ \\
\hline $\begin{array}{l}\text { Application } \\
\text { site }\end{array}$ & $\begin{array}{l}\text { Injection site reaction (49), Oral } \\
\text { candidiasis (1) }\end{array}$ \\
\hline $\begin{array}{l}\text { Skin and } \\
\text { appendages: }\end{array}$ & $\begin{array}{l}\text { Rash (31), Urticaria (24), Mouth ulcer } \\
\text { (3), Fixed drug eruption (FDE) (2), } \\
\text { Ecchymosis (2), Angioedema (14), } \\
\text { Pruritus (36), Steven Johnson syndrome } \\
\text { (1) }\end{array}$ \\
\hline
\end{tabular}


Causality assessment revealed that 228 ADRs (76\%) belonged to "probable" category, whereas 71 (23.6\%) were of "possible" type according to the WHO-UMC scale. No case could be labelled "certain", as rechallenge was not attempted.

Majority of the reactions (48\%) had Level 2 severity; i.e. drug was stopped due to ADR but no antidote or other treatment was required. $27 \%$ of the reactions had level 3 severity i.e. drug was stopped, and an antidote or other treatment was required.

\section{DISCUSSION}

Our study showed that women were commonly affected with male: female ratio of 1: 1.38. Agaard et al, reported $60 \%$ ADRs in females and Doshi et al. showed that both genders were equally affected. ${ }^{8,9}$

Authors also observed that adults were most commonly affected. While it has been reported by Arulmani et al, that ADRs are more common in children and elderly. ${ }^{10}$ This difference may be due to lesser number of ADR reports from paediatrics in the present study.

Skin and its appendages along with gastrointestinal tract were the common targets for ADRs. Our observations are synonymous with Giardina et al. ${ }^{11}$ However Kamalaraj et al, and Sriram et al. opine that the most common system involved is GIT. ${ }^{12,13}$

Interestingly, liver and biliary system ADRs were unexpectedly low in the present study. $179(60 \%)$ of ADRs were type B / allergic reactions. Antibiotics-Penicillins and Cephalosporins- were the commonest causes of such ADRs. This may be due to the widespread but unavoidable use of parenteral antibiotics among inpatients in this tertiary care centre. Also, the involvement of dedicated monitoring staff increased the sensitivity of reporting.

There were 121 type A / dose related ADRs. Commonest significant dose related ADR was bleeding (7\%). This almost always occurred when patient was receiving a combination of antiplatelets and anticoagulants. In two instances, concomitant use of ceftriaxone / cefoperazone contributed to this.

Thus, the common culprits involved in hospital related reactions were antibiotics and antithrombotic agents. This agrees with data found in the prospective, multicentric study by Giardina et al.

Another common dose related ADR was hyperglycemia produced by steroids (4\%). All cases occurred in patients with asthma/COPD who received short courses of systemic steroids. In all cases, patients were treated with insulin/ OHA and the dose of steroid remained unchanged.

Another significant ADR was acute kidney injury produced by miscellaneous drugs (4\%); the commonest culprit being NSAIDS. Hyponatremia and hypokalemia by diuretics were also common ( $2 \%$ each).

The association of majority of ADRs $(76 \%)$ to causal drugs was probable in nature. In the rest $24 \%$ of cases, only a possible causality could be attributed. Such patients were either receiving multiple drugs or had multiple comorbidities. No case could be labelled "certain", as rechallenge was not attempted.

The development of ADRs had significant impacts on the treatment course. In majority of cases $(48 \%)$, the drug had to be stopped. Another set of patients $(27 \%)$ required additional interventions/ drugs to treat the ADR. In $15 \%$ of cases, it prolonged the duration of admission. These findings are important for all stakeholders of health care system as it leads to significant morbidity and financial burden on patients and hospitals.

This was a retrospective study, wherein all reported ADRs were recorded as precisely as possible. However, considering the number of patients seeking medical treatment at our centre and number of drugs available, there was definitely an underreporting of ADRs.

However, the identification and assessment of ADRs was made by trained professionals, through proper monitoring programs. Also, since majority of reports were from inpatients, information about treatment of ADRs and follow-up data till recovery was also accurately available.

Thus, this study provides updated information on ADR related hospital admissions that may allow the design of preventive strategies.

\section{CONCLUSION}

ADRs that occur during hospitalization or contributing to prolonged hospital stay are considerable. Antibiotics were the major causes of hypersensitivity reactions. Combined use of antiplatelets and anticoagulants caused bleeding; which often prolonged hospital stay.

Use of systemic steroids in asthma / COPD was associated with hyperglycemia and subsequent use of insulin.

Pharmacovigilance and ADR monitoring is the need of time. Our findings highlight the importance of the "monitors" dedicated to pharmacovigilance, to improve the quality of reporting. A robust ADR monitoring system and education of prescribers to closely monitor patients can help prevent, identify, and manage ADRs effectively.

\section{ACKNOWLEDGEMENTS}

The authors acknowledge the Indian Pharmacopeia Commission, for all support provided under pharmacovigilance Programme of India (PvPI) and WHO. We would also like to thank all the clinical pharmacists who participated in data collection and all the clinicians 
involved. Authors express our sincere gratitude to Dr. Lyla KN and Dr. Neeraja Kanumilli. Authors are also grateful to Mr. Sony Simon and Dr. Meera who helped us in doing the statistics part of this study.

Funding: No funding sources Conflict of interest: None declared

Ethical approval: The study was approved by the Institutional Ethics Committee

\section{REFERENCES}

1. World Health Organization. Safety of medicines. A guide to detecting and reporting adverse drug reactions. Why health professionals need to take action. Geneva World Health Organization. 2002. Available at: http://apps.who.int/medicinedocs/en/d/Jh2992e. Accessed 9 May 2018.

2. Jerry Avorn. The Role of Therapeutic Agents in Modern Medicine B: Drug Risks. In: C.J. van Boxtel, B. Santoso and I.R. Edwards, eds. Drug Benefits and Risks: International Textbook of Clinical Pharmacology, revised $2^{\text {nd }}$ Ed. Amsterdam: IOS Press; 2008:10-13.

3. The WHO Global ICSR Database System: Basic Facts. Available at: www.who.int/medicines/regulation/medicinessafety/about/drug_monitoring_prog/en. Accessed 13 May 2018.

4. Pharmacovigilance programme of India. List of ADR monitoring centers. Available at: http://www.ipc.gov.in/PvPI/adr.html. Accessed on 2 March 2018.

5. Pharmacovigilance programme of India 2010. CDSCO, Ministry of Health and Family Welfare, Government of India. 2010. Available at: http://cdsco.nic.in/pharmacovigilance.html. Accessed on 2017 March 25.

6. Aronson J, Ferner RE. Joining the DoTS: The new approach to classifying adverse drug reactions: BMJ 2003;327(1):1222.
7. Medical Dictionary for Regulatory Activities. Available at: http://www.meddramsso.com. Accessed o14 May 2018.

8. Agaard L, Strandell J, Melskens L, Petersen PS, Holme Hansen E. Global patterns of adverse drug reactions over a decade: Analyses of spontaneous reports to VigiBase ${ }^{\mathrm{TM}}$. Drug Saf. 2012;35:1171-82.

9. Doshi MS, Patel PP, Shah SP, Dikshit RK. Intensive monitoring of adverse drug reactions in hospitalized patients of two medical units at a tertiary care teaching hospital. J Pharmacol Pharmacother. 2012;3:308-13.

10. Arulmani R, Rajendran SD, Suresh B. Adverse drug reaction monitoring in a secondary care hospital in South India. Br J Clin Pharmacol. 2008;65:210-6.

11. Giardina C, Cutroneo PM, Mocciaro E, Russo GT, Mandraffino G, Basile G, et al. Adverse Drug Reactions in Hospitalized Patients: Results of the FORWARD (Facilitation of Reporting in Hospital Ward) Study. Frontiers in Pharmacol. 2018 Apr 11;9:350.

12. Kamalaraj R, Revathy J, Vijey Aanandhi M, Murugan M, Ramanakumar KPV. Incidence, severity and financial burden associated with suspected unexpected serious adverse reactions (SUSARs) that arise in clinical trials. Asian J Pharm Clin Res. 2012;5:198201.

13. Sriram S, Ghasemi A, Ramasamy R, Devi M, Balasubramanian R, Ravi TK. Prevalence of adverse drug reactions at a private tertiary care hospital in south India. J Res Med Sci. 2011;16:16-25.

Cite this article as: Abdul AP, Purushothaman S, Shajahan J. An analysis of the pattern and profile of adverse drug reactions reported at a tertiary care teaching hospital in Kerala, India: a retrospective record based observational study. Int J Basic Clin Pharmacol 2018;7:1715-20. 


\section{ANNEXURE I: WHO-UMC Causality Categories.}

\begin{tabular}{|l|l|}
\hline Causality term & Assessment criteria* \\
\hline Certain & $\begin{array}{l}\text { Event or laboratory test abnormality, with plausible time relationship to drug intake } \\
\text { - Cannot be explained by disease or other drugs } \\
\text { - Response to withdrawal plausible (pharmacologically, pathologically) } \\
\text { - Event definitive pharmacologically or phenomenologically (i.e. an objective and specific } \\
\text { medical disorder or a recognised pharmacological phenomenon) } \\
\text { - Rechallenge satisfactory, if necessary }\end{array}$ \\
\hline Probable/ & $\begin{array}{l}\text { Event or laboratory test abnormality, with reasonable time relationship to drug intake } \\
\text { - Unlikely to be attributed to disease or other drugs } \\
\text { - Response to withdrawal clinically reasonable } \\
\text { - Rechallenge not required }\end{array}$ \\
\hline Possible & $\begin{array}{l}\text { Event or laboratory test abnormality, with reasonable time relationship to drug intake } \\
\text { - Could also be explained by disease or other drugs } \\
\text { - Information on drug withdrawal may be lacking or unclear }\end{array}$ \\
\hline Unlikely & $\begin{array}{l}\text { Event or laboratory test abnormality, with a time to drug intake that makes a relationship } \\
\text { improbable (but not impossible) } \\
\text { - Disease or other drugs provide plausible explanations }\end{array}$ \\
\hline Conditional/ & $\begin{array}{l}\text { Event or laboratory test abnormality } \\
\text { - More data for proper assessment needed, or } \\
\text { - Additional data under examination }\end{array}$ \\
\hline Unclassified & $\begin{array}{l}\text { Report suggesting an adverse reaction } \\
\text { - Cannot be judged because information is insufficient or contradictory } \\
\text { • Data cannot be supplemented or verified }\end{array}$ \\
\hline Unclassifiable & \\
\hline
\end{tabular}

